\title{
Music and Language in Ancient Verse: The Dynamics of an Antagonistic Concord
}

\author{
Fionn Bennett
}

Received: 29 September 2015; Accepted: 12 January 2016; Published: 20 January 2016

Academic Editor: Jacob-Ivan Eidt

C.I.R.L.E.P. (Centre Interdisciplinaire de Recherche sur les Langues et la Pensée)—EA 4299, Université de Reims, 51096 Reims, France; fionn.bennett@univ-reims.fr; Tel.: +33(0)-326-913-619

\begin{abstract}
In antiquity, the relationship between "music", "poetry", and "language" was very different from the way they relate to each other today, for back then each of these mediums was endowed with a distinct, independent signifying code expressing a semiosis all its own. However, these separate "semiospheres" nonetheless never ceased growing towards and into one another. This is so because music and "melic" poetry were believed to have the capacity to denote something ordinary language could not denote but could not do without, namely "etymonic truth". As a result, the users of ordinary language were obsessed with divining the "hyponoia" poets encoded in music and chant. Above all, they wanted this hyponoia to constitute the signifié of their language. For this reason, the meaning expressed in language was subject to a process in which it was constantly being "deported" from its ordinary acceptations and transported towards meanings encoded in music. However, this "deterritorialization" of ordinary meaning never resulted in a full "reterritorialization" upon the terrain of the truth encoded in music. Musicians and poets would not tolerate it. As far as they were concerned, music and poetry would cease being "truthful" if the semiosis they conveyed and the semiosis conveyed by language were interchangeable. For, again, as a signifying code, prosaic language was sui generis incapable of representing the truth. Hence, the relationship between these three codes consisted of a sort of intersemiotic dynamic equilibrium in which language was continuously evolving towards a non-linguistic expression of meaning which conferred truth upon it and what it means. And yet the music and poetry which were the source of that truth deliberately kept language from consummating the aspiration of accosting the truth they encoded. This paper explores the mechanics of this intersemiotic dynamic equilibrium.
\end{abstract}

Keywords: Ancient Greek Verse; diglossia; bi-narrativity and "Poikilia"; musical meaning in "Song Culture"; music and truth; music in poetry; etymology and poetry; semiotics of melic poetry; intermedial intertextuality

\section{Introduction: An Intersemiotic "Triple Bind"}

This article deals with the intersemiotic relationship between and among three different codes or "semiospheres" corresponding to three different media. These media are Music, Ordinary Language, and Poetry where "Poetry" refers to the composition and performance of verse preceded by a hymnic

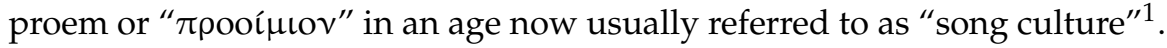

This is necessarily a risky undertaking. First, because the time we are dealing with was an "oral" culture of which we possess no reliable first-hand evidence. Second, conjecturing about

1 On "song culture", $c f$. esp. ([1], pp. 3-4) and passim. The terminus ad quem of the age of song culture is the mid-5th century BCE. A terminus a quo is impossible to determine. 
it by extrapolating from the evidence and testimonia that have survived will always be subject to second-guessing and controversy. Finally, even if the hymn-prefaced variety of "melic" poetry we are interested in is a form of "song" now recognized as the kernel from which many other poetic "genres" evolved ([2], p. 6; [3], p. 360), this, by itself, does not allow us to assume there is nothing unproblematic in referring to it singulare tantum ${ }^{2}$. That would be tantamount to ignoring differences among specialists in poetics over a host of hotly debated questions. For example, the details of the way hymn-prefaced poetic compositions and performances evolved from local, cult worship to large-scale "Panhellenic" public performances, and how this is likely to have entrained a "shift from an aoidic to a rhapsodic mode of performance" ([4], p. 497); uncertainty about the protocols governing the division of labor between the singing bard, the chorus, the citharode and the aulos player; how the "laicization" of the Hellenic paideia brought about a transformation of the use of song and poetry for mainly religious purposes to more "literary" applications, and why this apparent transformation conceals a continuity as much as it reveals a discontinuity ([5], pp. 10,395-96; [6], pp. 9-10); the process whereby Poetry grew apart from Song, unmetered Prose from Poetry, and the subdivision of Poetry into a multitude of "genres", e.g., paeans, dithyrambs, prosodia, partheneia, threni, nomes, etc. ([2], pp. 10-13; [3], pp. 108ff.); and, finally, the vexed question of the extent to which the modern classification of poetic genres is applicable to the description and analysis of melic poetry in "song culture"3.

Still, despite the caveats needed to make allowances for these and other equally weighty exegetical and hermeneutic challenges, some things are clear. Namely, that prefacing a poetic recital with a hymn was a "performative" ritual act consisting of invoking or summoning one cosmic agency or another ${ }^{4}$. It is also fairly evident that the performance of verse that followed a hymnic proem underwent a transformation that made it very different from verse recital unaccompanied by such a proem. Finally it seems possible to reconstruct, albeit only in terms of general principles, not just the results this sort of rite was undertaken to bring about but also some the expedients it was thought best to resort to to make that happen.

And it is here, in the penumbra of uncertainty surrounding these relative certainties, that this paper places its question marks. What is supposed to happen to melic verse that benefited from the invocation of the Muses or of the Gods for whom the Muses were emissaries? In what way and with what intention was this supposed change effected? And if change there was, what form did it take?

To wend our way to some sort of clarity on these questions we begin by puzzling over what I will call a semiotic paradox or "triple bind". Namely the fact that each of the media we mentioned above-Music, Ordinary Language, and Poetry-encoded a "semiosis" which operated completely independently of the semiosis peculiar to the other two media and yet, at the same time, all three semioses were totally dependent on each other. They were independent from each other because-in principle-the semiosis specific to each code was irreducible to the semiosis specific to the other two codes. And yet these three codes were totally interdependent because their respective semiotic operations were untenable without resources they were incapable of supplying themselves and were

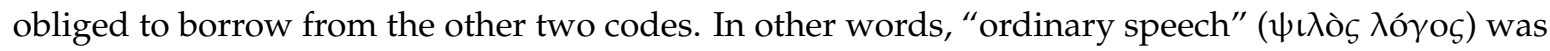
semiotically inoperable without properties to be found only in music ( $\mu \varepsilon \dot{\varepsilon} \lambda \varsigma, \mu \mathrm{o} \lambda \pi \tilde{\eta}$, etc.) and poetry

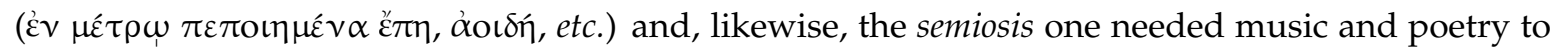
express were dependent on semiotic resources they had to borrow from ordinary speech. Hence the relationship between and among these three codes or semiospheres described a sort of "inter-semiotic dynamic equilibrium" characterized by a simultaneous attraction-repulsion, promiscuity-chastity,

2 Jenny Strauss Clay speaks for more than the Homeric Hymns when she observes: "The history and prehistory of the compositions that have come down to us as the Homeric Hymns may, then, not be monolithic, but complex and multiple with varied functions at different periods, adapted to changing situations and occasions of performance" ([4], p. 498).

3 Cf. ([7], 38ff.; [8], p. 163) but above all ([9], pp. 109-10): "La poésie archä̈que grecque ne se prête décidément pas aux distinctions génériques modernes".

4 Cf. ([2], pp. 6-7; [4], pp. 493-94; [10], pp. 45ff.; [11], p. 6). For a discussion of the applicability of "performative utterance" to ritual "singing for the Gods", see ([3], pp. 8-9; [5], pp. 47-53; [11], pp. 305ff.; [12], pp. 202-3). 
afference-efference, semiotic interoperability-semiotic non-interoperability. We could also say that these three codes were continually growing towards and into each other without ever consummating what one might think should be the logical outcome of such a process. Namely that all three converge and fuse into a single medium, a single code and a single semiosis. So, what we have to ask ourselves is:

(1) What was semiotically specific to each of these three codes or semiospheres;

(2) Why did they constitute semiotic "celibacies"; and, finally,

(3) How, despite their semiotic celibacy, does some sort of semiotic "cross-fertilization" nonetheless take place?

Let us start by looking at hymn-prefaced melic poetry.

\section{Hymn-Prefaced Melic Poetry in "Song Culture": Diglossia and Bi-Narrativity}

In a way, the specificity of the semiosis peculiar to hymn-prefaced poetry was to have no specificity ${ }^{5}$. For, semiotically speaking, it was simply a medium occupied by the semiosis specific to ordinary, everyday speech and the semiosis specific to "musical" arrangements of sound. In other words, any "meaning" hymn-prefaced poetry created through an unusual use of language never in the end separated that meaning from linguistic meaning and any "meaning" it created through melody, tone, meter, or rhythm had, in the final analysis, to be attributed to the "music" which accompanied the poetic recital ([17], pp. 133, 249-51; [18], pp. 324-28).

However, if this variety of poetry had no semiotic specificity, that does not mean there was nothing sui generis about it as an art form. This is obvious from the fact that its composition was reserved for highly-trained phoneticians ([19], p. 127; [20]; [21]; pp. 112-13; [22], p. 30-31; [23], pp. 54-55; [24]), for it took a long time to master the metaplasmatic, melismatic, and metrical tricks one needed to know to be able to compose verse which was "coherent" both as ordinary speech and as music. And here the expressions "musical coherence" and "lexical coherence" must be understood in a very specific and precise sense, for poetry in earlier times was composed to be "di-glossic" and "bi-narrative"6. That is to say, it consisted of two languages, recounting two narratives with the help of two distinct arrangements of sound, one in music and the other in ordinary, everyday speech. That is why specialists in comparative poetics are at pains to make us aware that in ancient verse "an entire set of resonances can be found in every single word and morpheme of one single utterance" ([26], p. 91) and that any hope of fruitful study of the subject depends on deciphering these resonances to find "meanings not always easily perceived from the surface denotations of the words themselves" ([27], p. 92). What they

5 Tropes and figures and "metaphorical" uses of language did of course exist and were widely used in early verse (cf., for ex., [13], p. 71f.) and of course this "stylistic" distinctiveness set poetic uses of language apart from ordinary "unmarked" language and did impact how the audience apprehended whatever is referred to by them. However, along with Heidegger ([14], p. 89) and Derrida ([15], p. 274ff.), we accept that what "metaphorical" uses of language refer or allude to is never anything one could not refer to with normal words and it was the sameness of the referent for both the "literal" and "metaphorical" meanings of significant words which means that even if marked, "poetic" uses of language are "stylistically" quite distinct, there is nothing semiotically or "apophantically" sui generis about them. Since we see verse and ordinary language as being "stylistically" very different, but nonetheless sharing the same referentiality, it should be clear that we in no way contest what Mikhail Bakhtin says about the relationship linking "primary" and "complex speech genres" ([16], pp. 60-67). At least we do not do so to the extent that he allows complex speech genres to absorb signifiés borrowed from primary speech genres and then profoundly modify how they should be interpreted without withal making them different signifés.

6 A number of well-attested facts encourage us to affirm this. First of all the frequent use of " $\pi$ oเki $\lambda$ o $\varsigma$ compounds"

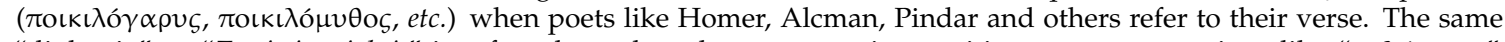

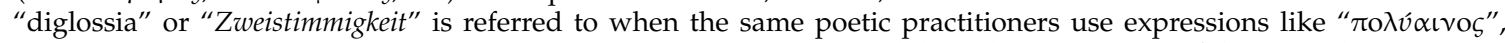

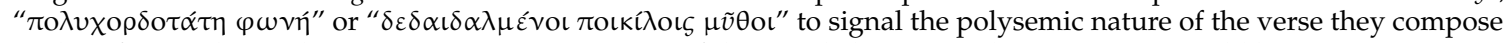
and perform. Obviously, as an anonymous reviewer of this article has pointed out to me, it would be unwise to ignore

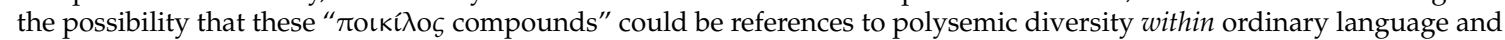
within the semiosis communicated through music. This is unquestionably the case for-as we know from Christos Tsagalis' The Oral Palimpsest [25]— the ordinary language of verse was thematically, linguistically, and semantically multi-layered.

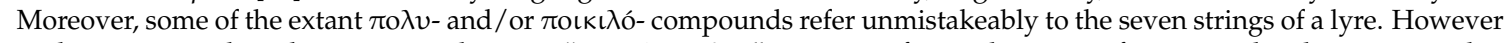

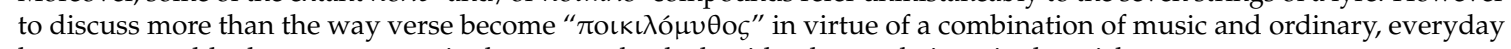
language would take us on to terrain that cannot be dealt with adequately in a single article. 
are referring to in saying this is something Saussure and Mallarmé had (re)discovered over a century ago; namely, that verse accommodated two semioses, one "unmarked" and encoded in words and one "marked" and encoded in music. So, unless one could discern both of these separate arrangements of sound, and therefore both of the narratives recounted through them, the verse, so constructed, failed in its main purpose of being di-glossic and bi-narrative.

Why, then, was it important for poetry to be "diglossic"? What need was satisfied by combining a narrative encoded in music with a separate one encoded in words to versify about one's objects? The short answer to that question would be to say that the goal was to represent things and events to the power of their "totality" or "integrality". However, that, like most short answers, is a little too elliptic. What do we mean by "totality"? Why did the poet have to use two codes to signify it? Why could he not do that using only one code? Let us start with a preliminary remark about the distinction the Hellenes of song culture made between musical semiosis and verbal semiosis.

\section{3. "Alethophoric" Music, "Doxastic" and "Pseudophoric" Ordinary Language}

To simplify a great deal, we can say that this difference boils down to the fact that, unlike the

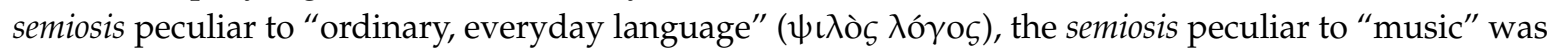
"alethophoric". In other words, it and it alone was able to represent the "truth" about the objects sung about in poetry ${ }^{7}$. Why could words not signify the "truth" or "reality" about their referents? Because people back then believed that the only thing words are good for representing is the way things seem to be "sub specie hominis", i.e., what mortals perceive the reality of phenomena to be. Understandably, this was considered to be unreliable for determining what things "truly are" because perceptions of things differ from percipient to percipient ${ }^{8}$. Hence, short of postulating some supervenient, supra-sensual reference or norm for determining truth, there is no way to ascertain whose perceptions are "correct" - only "misological" doubts that anybody's perception apprehends anything as what it "really is" ${ }^{\prime \prime}$. So, in as much as words were limited to representing this contingent, doxastic or "ontic" aspect of what things are, they did not and could not tell the truth. In addition to this sort of undecidability, people noticed that words could be used by some men to alter the perceptions of other men about the "reality" of the things or events their words refer to. What is more, they could do that not just without regard for what their referents "really are" but also to create perceptions of those referents which the speaker knows those things are not. So, because prosaic speech was (i) prey to unreliable perceptions; and (ii) could be used to propagate deliberate falsehood, it was, as a semiosis, unreliable for representing the "truth" or "reality" of anything.

Still we should not exaggerate the extent to which people believed that the uncertainties of words made them incapable of signifying "truth" or "reality". In any event no one, not even the Sophists, believed that words had no other purpose than to refer specifically to error and illusion. Rather the contrary; it was believed that words had both the ability and the obligation to be exact phonetic replicas of the denotata for which they stood. In fact-as we know from the passages of the Cratylus devoted to

7 Though the "distance" separating "truth-bearing", "hieratic" semiosis from the error-prone semiosis of "profane", everyday speech is generally recognized in specialized studies ([26], pp. 181-83; [28], pp. 15f.; [29], pp. 81-82, 95-96), few acknowledge the certainty that this "obscure", hieratic semiosis was encoded in the musical arrangements of sound which accompanied and modulated melic verse (on which see [30], p. 41f.; [31], pp. 56-57, 64-66; [32]; [33], pp. 5-19). Yet, as we will see below, there is ample proof of this in our sources.

8 This is what is meant by the oft repeated remark among Poets and Philosophers that men "neither see nor hear anything accurately" (cf. [34], p. 61 on AESCHYLus (Persians, 266), SOPHOCLES (Oedipus the King, 6, 1238 and Trachines, 747), EuRIPIDES (Suppliants, 684, Trojan Women, 481-82, Iphigenia in Taurus, 901, Hippolytus, 86 and Medea, 652) and PLATO (Phaedo, 65b and Phaedrus, 250bc). Cf. also HOMER, Iliad, 2.484-93; PINDAR, Olympian Ode, 1.28-29; HerACLITUS, Frr. DK 22B 1, 54, 107 and 123; PARMENIDES, Fr. DK28B 6, ll. 5-10 and PlATO, Republic, VII, i. Obviously, as an anonymous reviewer has pointed out to me, it is altogether possible that the views expressed by these poets and thinkers were not shared by non-poets and non-philosophers. However the scarcely contestable case made by Erwin Rohde and E.R. Dodds about the irrational, animistic, and hylozoist character of early Hellenic ideas about the world they dwelt in makes it safe to assume that they did not demur from the views of the poets and thinkers we cited above.

9 For the classical demonstration of this point, cf. Plato's Theatetus and Phaedo. 
the language theory of the dialogue's eponymous hero-they believed that words were not words if they were not, quite literally, "sound statues" ( $\alpha \gamma \alpha \hat{\alpha} \lambda \mu \alpha \tau \alpha \varphi \omega \vee \eta ் \varepsilon v \tau \alpha)$ of their correlative referents' "true" ontological character ${ }^{10}$.

What, then, secured the famed "consubstantiality" or "co-naturalité"11 linking the meaning of words and the "true nature" of their correlative denotata? Alternately, how does one (i) sculpt sound into an exact "acoustical replica" of various phenomena; and then (ii) include that sound in the phonetic substrate of the names of those phenomena thereby making the latter the "naturally correct" signifier of the things they stand for?

We have already suggested where the answer to this question is to be found. "Music" or rather melodized tones and metered rhythms is what was used to encode what in the Cratylus is referred to as

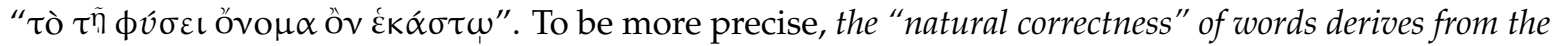
meaning or "enigmatic hyponoia"12 poets conferred on the things they chanted about through the "music" they used when reciting poetry. For, as the reader will no doubt know, verse was not just "recited" in ordinary, everyday speech. It was accompanied by musical arrangements of sound produced by voice, kithara, or aulos. And it was accompanied by "music" not just for ornamentation, though that was also a factor. The real importance of the presence of music in verse was that thanks to this music one could discern the "truth" about what things "really are". Which means that we have at least five further questions to answer.

(1) What did the "truth" / "reality" of existing things consist of?

(2) How did music encode this truth?

(3) In what sense did the Poet-Hymnode make this musically encoded truth the "etymon" of the ordinary words and language he used in verse?

(4) Why was it impossible for words to "semantically accost" this etymon directly even though it was "their" etymon? And finally,

(5) How were prosaic words semiotically impacted by this musically-encoded etymonic meaning despite and ultimately because of this inter-translative impasse?

The answer to the first question will come as no surprise to anyone who is familiar with studies on Creation Myths in the area of Comparative Mythology. For they will know that, like peoples in other climes, the Hellenes of times bygone conceived the "reality" or "truth" of phenomena to consist of their "cosmic" signification. What this should be taken to mean can be elucidated with a summary reminder of what mythopoeic representations of cosmogony would suggest about the way the Hellenes of song culture conceived the origin and nature of physical reality.

\section{The Cosmological and Ontological Foundations of Musical Semiosis}

Basically, the early Hellenes believed that the world they lived in was a mesocosm which was

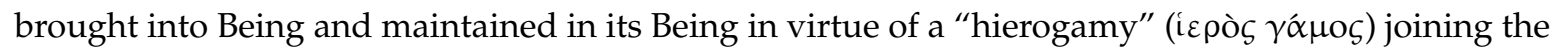
sky above and the earth below in an "act of love, Hesiod's Theogony being the archetypal example.

10 Cratylus, 424c. cf. also ([18], p. 38; [35], p. 12f). Despite traces of extra-Hellenic influences in it, we consider Proclus's analysis and commentary of Plato's Cratylus—-treated in [35]— to be a useful reference for elucidating the whole idea of words and language as " $\dot{\alpha} \gamma \alpha \dot{\alpha} \lambda \mu \alpha \tau \alpha \phi \omega v \eta ́ \varepsilon \gamma \tau \alpha$ ".

11 Cf. Cratylus, 393d, 422d, 428e and 432e.

12 Specialist studies of the term "v́ $\pi$ óvoเ $\alpha$ " are at pains to point out that this word fails to be adequately understood if it is merely translated as "meta-thought" or "meta-message". This is so because it belongs to a history of thought on varieties of "meta-thought" in which "v́róvol $\alpha$ " is distinguished from and sometimes contrasted with related terms such as ainigma, allegory, symbolon, and their cognates (cf., inter alia, [36], pp. 45-59; [37], pp. 23 and passim). However, going over all this is not necessary for our purposes in this paper. For us all this term should be taken to mean is a message or "ainos" the poet wished to communicate through his versification because it relates something essential about his verse's subject or subject matter but which cannot be expressed-or understood-by relying only on the "literal" meanings of the ordinary words used in verse. How, then, was this "ainos" expressed and understood? Our contention in these pages is that, in song culture, the semiotic resource artists and audiences relied on most to encode and decode this gnomic or didactic content was melodic and rhythmic arrangements of sound. 
Moreover, they believed that the ontogenetic role played by this hierogamy in relation to the existence of the mesocosm also applied to the existence of everything and everybody inhabiting this mesocosm. Necessarily so, for without it, it was not just this or that thing or this or that category of things which did not exist. Nothing existed at all. As a result, to speak of what any existing thing "really is" qua existing thing, one needs to speak of it as being "en abyme" in relation to these cosmopoietic agencies.

Obviously, because the panoply of tools used by poets to compose verse was so great (gnomic utterance, mythological symbolism, metaphor, allegory, enigma, etc.), it would be folly to suggest that there was ever only one way to do this, and certainly it would be false to say that ordinary, profane, "idiotic" words and language could not be used to do so. For proof to the contrary one has only to look at Hesiod's Theogony or the ekphrastic account of "Achilles Shield" in the Iliad (XVIII, 478-617) or any number of passages in the Homeric Hymns or Pindar's epinician Odes. After all, what are they if not accounts of the creation of the cosmos and depictions of the cosmically ordained place of mortals in it carried out with the help of the (allegorical) expressive powers of ordinary words and language? ${ }^{13}$

Still, when the hymn-chanting " $\alpha$ oı $\delta$ ' $\varsigma$ " of yore wanted to portray the objects of their versification to the power of their cosmic significance, it was far more common for them to use music to do it. Five different sources corroborate this. First, a number of well-known passages in Plato ${ }^{14}$; second, and more cryptically, the remains of Pythagorean ideas on music as a semiotic system, in particular in the enigmatic oo $\mu \beta 0 \lambda \alpha$ preserved by Iamblichus ${ }^{15}$; third, certain passages of the Homeric Hymns ${ }^{16}$; fourth, legends about the origin of music, for example the fragments of the Pindaric Hymn to Zeus in Aelius Aristides, 2.142 ${ }^{17}$; and finally, in the fragments of the verse of various archaic poets ([39], pp. 212-13), for some of which we are fortunate enough to have some very competent analyses: for example, M.L. West's commentary of Alcman ([40], pp. 1-15). To have a sense of the basic idea that is operative in these sources, a single passage of Plato's Laws-653d-654b-will suffice as an illustration.

What this passage says is that melodically- and rhythmically-modulated voice- or instrument-generated sounds are the way Apollo, Dionysus, and the Muses share the company of mortals on those occasions when melic verse is performed before them by an inspired dot $\delta$ ós. So, as Apollo and Dionysus are symbols of the sky and the earth and the role they play in cosmopoiesis, at least three things follow: (1) cosmos-creating uranian and chthonian agencies have some sort of acoustic signature; (2) the accredited dòoı́s can hear that signature and can replicate or "score" it in melodic and rhythmic arrangements of sound and in this guise; (3) inform his public of the role these cosmopoietic agencies play in influencing events going on in the world they live in. Alternately, we can say that all it took for the chanting poet to "epi-phon-ize" the "truth" about the objects he sang of was to (1) explore "happenings above the sky and below the earth"18; (2) apprehend the "rumor" of the way the cosmopoietic agencies lurking there do what they have to do so the cosmos can emerge as the "complexity" we perceive by observing what is going on around us; (3) ascertain how this cosmic drama pertains to the object of versification; (4) encode this intelligence in melodically and rhythmically modulated sounds and through the chanted lays containing those sounds; (5) apprise his audience of what he had learned about the cosmic significance of whatever he sang about.

Why was this intelligence encoded in melody and metered rhythms? Because not only did the poet's audience require that there be nothing "creative" or "make believe" in what he recounted; they also expected what he said to be as accurate a portrayal of the truth as possible. To satisfy this requirement, evidently no medium or code was believed to be as reliable as music—or

13 For a good illustration of the way metaphorical and allegorical symbolism could be used to encode cosmic or hieratic hyponoia, cf. ([29], pp. 81f.; [37]).

14 Laws, 653d-654b, 664e, 672d, 967e; Republic, 530d-531d, 616e-617c; Timaeus, 47be and Cratylus, 405cd.

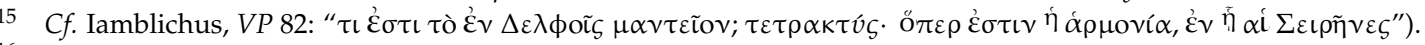

16 e.g., Homeric Hymn to Apollo, 130-32 and Homeric Hymn to Hermes, 423-35.

17 On this and for a sampling of similar supporting evidence, $c f$. ([38], pp. 264-67).

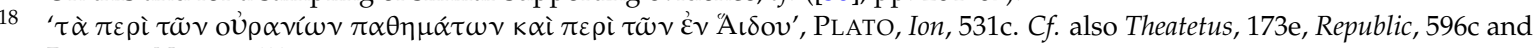
PINDAR Nem., x, 87sq. 
rather, and to be more precise, the tones and cadences or melodies and meter which modulated the semantically-determinable content of the verse they composed ${ }^{19}$. What made it easy for Greek musicians to satisfy this expectation is the fact that melody and meter in Greek music were governed by tonal and rhythmic "combinatories" which were structurally and even functionally comparable to the phonetic combinatory the Greeks used to synthesize ordinary, everyday words and language. We can illustrate this remarkable fact through a commentary of what we see in Figure 1 below.

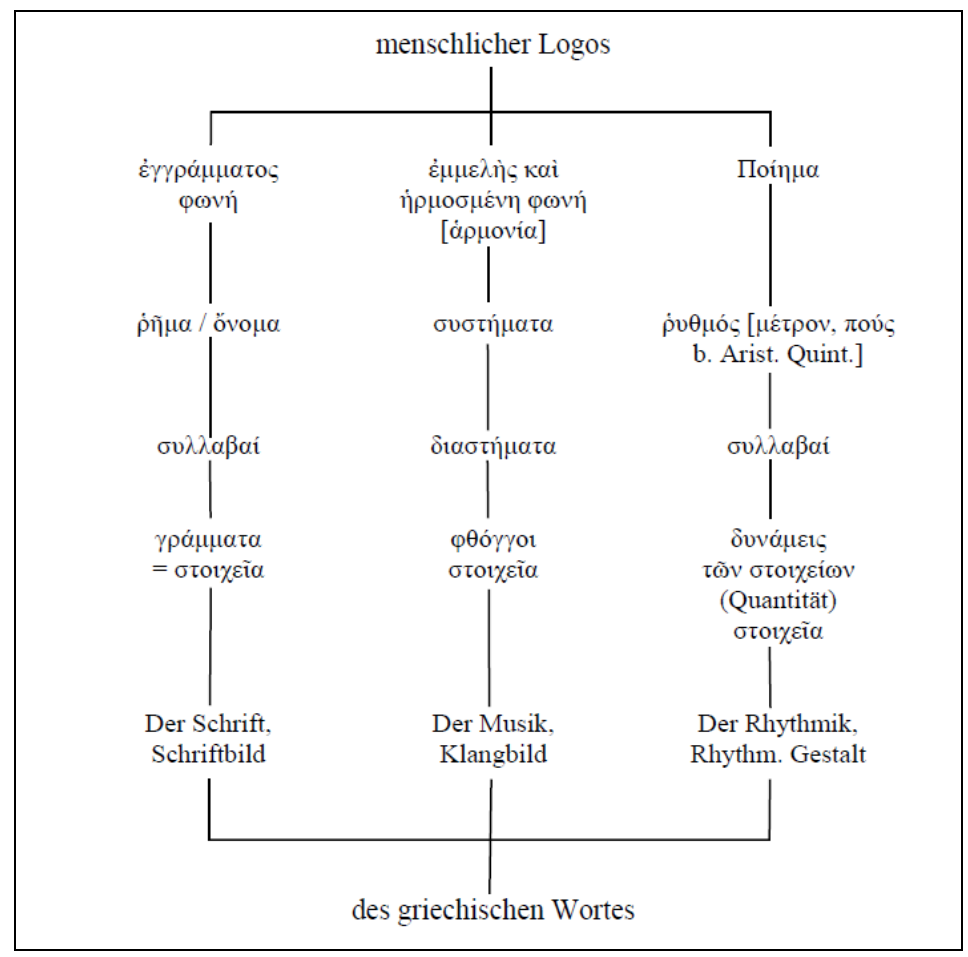

Figure 1. Hermann Koller's Presentation of the Phonetic, Melodic and Rhythmic Combinatories which organized Language and Music in Early Greece.

This diagram is copied from an article entitled "Stoicheion" published in 1955 by the noted philologist Hermann Koller [32]. It is distilled from Koller's analysis of a plurality of sources: the ideas of the 2nd century Peripatetic Adrastus of Aphrodisias set forth in Theon Smyrnaeus' De utilitate mathematicae (49.6-50.3 Hiller), key passages in the Platonic dialogues the Philebus (17a-d) and the Cratylus (424c-e) as well as information about early music theory drawn from Aristotle's Poetics, Aristides Quintilianus, and Dionysius of Halicarnassus. Needless to say, we decline to hazard a guess as to the validity of Koller's interpretation. Indeed we willingly concede that, given the nature of the subject Koller is dealing with, it is unlikely he has hit on the final, definitive solution to the enigma he is interested in. However, as it is clearly his goal to shed light on the "die älteste sprachlich-musikalische Theorie der Griechen", his analysis is a good departure point for penetrating into a little known domain, but one which is central to the question of the semiotics and semantics of music in antiquity.

So, what do we see in this diagram? We see three vertical columns divided into four horizontal strata. The columns represent three distinct sound "combinatories". On the left there is a phonetic combinatory detailing the elemental and supra-segmental "parts of speech". In the middle there is a tonal combinatory peculiar to melodic composition. On the right there is a metric combinatory describing the elemental and supra-segmental parts of poetic composition. But these three columns

19 Cf. ([41], pp. 42-43) and compare with [42] where Frits STAAL describes the meter of poetry in the Vedas as being more reliable than writing or even digital data storage systems as a way to encode and store information! 
are not just distinct. By virtue of the four strata contained in each of them, they are also very much related. For what these strata represent is an "isomorphic", "symmetrical", or "analogical" relationship between the elements of each combinatory at the level of each of the four strata they contain. In other words, the stoicheia at the bottom of the first column are in the same formal relationship to each of the other three strata above it as the stoicheia at the bottom of the second and third columns are to

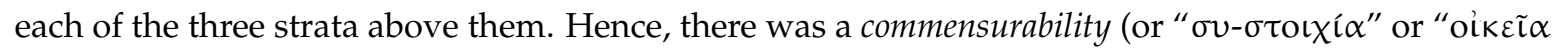
$\dot{\alpha} \lambda \lambda \hat{\eta} \lambda \mathrm{ors}_{\text {") }}$ ) between the elements and combinations of element in the Greek language and the elements and combinations of elements in the Greek musical system, meaning that among the Hellenes of old, the constituents of speech could be structured like a musical work and the constituents of their musical works could be structured like a language.

What advantage for melic poetry is entailed by this common structuring? One obvious answer is that this makes it easier to "stitch together" formulaic sequences of language which match a pre-chosen meter or melody. Another, we maintain, was to make melic verse "bi-natured" or "duplicitous" ( $\delta\llcorner\varphi v \tilde{\eta}$, $\delta \iota \pi \lambda \mathrm{o} \tilde{v} \zeta)$ the way Plato uses these qualifiers in the Cratylus $(408 \mathrm{~b}-\mathrm{d})$ to describe language as being both "truthful" because of something about it which is imputable to the divine and "false" because of the contribution mortals make to its constitution. As this point is critical for us, let us explain what we assume this means and how it is relevant to the semiotics of hymn-prefaced melic verse in song culture.

If the segmental and supra-segmental elements which organize melody and meter in the Greek musical system were structurally identical to those used to organize the phonetics of words and ordinary language in the Greek language, Greek musicians could use melodized tones and metered rhythms to do what ordinary language allowed them to do, namely, to denote things and to compose narratives about them. However, if you could use melody and meter to do that, the kind of information you encode while doing so is not the same as the information you encode when you use everyday words and language to denote and to narrate. For, as we have already seen, ordinary language represents how things seem "sub specie hominis"-how mortals perceive them to be, but when they are "epiphonized" in tone and rhythm by an inspired doเ $\delta$ ó $\varsigma$ or a trained and qualified rhapsode, we are hearing of what they are and how they are to the power of their cosmopoietic and ontogenetic significance. In any event, this is something which is widely assumed to be true of the way the masters of mantra shastra in India wove "bijas" and "ragas" together to compose the Vedas [43,44]. From research carried out on the Pythagorean "tétractys", it was certainly true of versification in the Greco-Roman tradition, too $[40,45,46]$.

But what made that claim credible? What is supposed to make the melody and meter in poetry a sort of mimetic echo of the Uranian and Chthonian agencies which account for the emergence and Dasein of the things and events the dỏot $\delta$ s or rhapsode chanted about?

\section{Melodized Tones and Metered Rhythms as a Cosmological Source Code}

To prevent things becoming overly technical, we can simplify by saying that the trick consisted of creating a mimetic reciprocity between two systems of numbers. One system of numbers for distinguishing and representing different phonetic phenomena, the other system of numbers for encoding the "laws of nature", in particular the laws governing astronomical, meteorological, and geological phenomena and other processes which are essential for life on earth. Once these two systems of numbers are established, the challenge then consists of establishing a one-to-one relationship between the elements and combinations of elements in one system and the elements and combinations of elements in the other system. On the basis of this correlation, particular configurations of sound are ipso facto acoustical replicas of particular configurations of life-creating cosmic activity. In other words, thanks to the music accompanying and modulating verse, the thing chanted about in it is mise en abyme in relation to the cosmopoietic agencies to which it owes its emergence and Dasein.

But there is a problem here: all this only tells us how melody and rhythm are supposed to be in a semiotic relationship to the "cosmopoietic truth" of the objects they denote and are used to relate that truth. It does not tell us how the "truth" encoded in "music" was transferred to the words and 
ordinary speech which accompanied this "alethophoric" music and how, for that reason, the truth encoded in music becomes a semiotic property $(\delta \dot{v} v \alpha \mu \mathrm{s})$ of those profane words and language. Clarity on this point is essential if we want to solve the semiotic paradox I mentioned at the outset. For, as we have seen, words were not considered to be words unless their significance was linked to and even consubstantial with what their signifiés "really are", and the link between (a) the "true meaning" of words; and (b) the "true nature" of their denotata depended on a link between; (c) the ordinary meanings of ordinary words; and (d) the "true" meaning of those ordinary words encoded in music. Necessarily so, because music was the only code which was capable of authentically representing the "truth" about what things truly are.

However, as we have also seen, the distance separating the semiosis specific to "pseudophoric" words and the semiosis which was specific to "alethophoric" music was both immense and, in theory, unbridgeable. Which means that, in principle, no semiotic cross-fertilization could take place. Hence a semiotic paradox: words had to mean what their expressive powers were incapable of expressing.

Granted, but—as I pointed out in an earlier article [47]—even if you could not, in principle, translate the hieratic hyponoia encoded in music into the profane semiosis encoded in ordinary speech, this does not mean that, despite this theoretical impossibility, no one ever tried to do so. Indeed, all the signs indicate that the desire to uncover the hyponoia chanting poets encoded in melody and meter was insatiable and the efforts to gratify that desire both strenuous and sustained. In addition, we should not assume that the non-poetic publics the $\alpha$ ot $\delta$ ó $\varsigma$ sang for were so ignorant of the way he composed verse that the hieratic hyponoia he encoded in music was impossible to decipher ${ }^{20}$. This, after all, was a public which had received the quasi-totality of its education $(\pi \alpha \iota \delta \varepsilon i \alpha)$ through and as $\mu$ ov $\sigma \kappa \eta^{21}$. In any event, it was these attempts to translate poetic wisdom into terms understood by the uninitiated which had an intersemiotic incidence on the vernacular, demotic, idiotic speech of the proverbial man and woman in the street, for it is unthinkable that people actively sought to substitute the "ordinary" meanings of words with the "poetic" meaning of those same words without this having a transformative effect on non-poetic, "demotic" language and language use.

How, then, did that happen? By what mechanism does this intersemiotic cross-fertilization between prosaic semiosis and musical semiosis take place? Without suggesting there was only one way to do this, we will answer this question by considering afresh one implausibly under-valued exegetical sport practiced by all classes of men and women in antiquity. We refer to "etymology" or to say the same

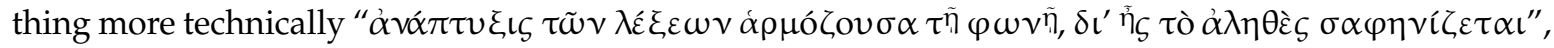
which means "unfolding the phonetic properties of words to bring to light the truth they conceal" 22 .

\section{The Role of Etymology in "Deterritorializing" the Ordinary Meaning of Words and "Reterritorializing" them on the Ground of Poetic Truth}

By all accounts people in ages bygone were obsessed with picking words and language to pieces to uncover the "truth" that was dissimulated by their normal, everyday meanings, and, it is true, the fruits of their labors were, from the perspective of the modern philology, far from impressive ${ }^{23}$. For popular

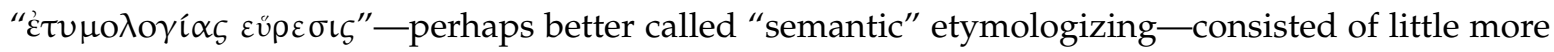
than dissecting words into pieces which were recombinable in any way the would-be etymologists needed them to be combined to concoct almost any "original meaning" he or she pleased ${ }^{24}$. Moreover,

20 Cf., inter alia, ([8], p. 164; [25], 45-46; [34], pp. 45-46; [48], p. 227; [49], p. 24; [50], pp. 50-51).

21 Plato, Protagoras, 326ab, Timaeus, 80b, Republic, 376e, 401d and Laws, 654a-d, 672e, 666d. Cf. also [51], pp. 43, 76; [52], pp. 15, 22, 184, 365ff.

22 Besides ([53], p. 135), n. 1, cf. also [36,54].

23 Cf. ([36], p. 61) for the case that in Homer, Aeschylus, Heraclitus and Democritus "[la] maladie étymologique, à l'état aigu chez les Stö̈ciens, se retrouve à l'état endémique dans toute l'antiquité". For the adjustments that are necessary to add to take into consideration the evolution of etymological praxes throughout this very long period, the readers is advised to consult more recent studies, e.g., ([55], pp. 7-21).

24 The very harsh judgments made about the evidence we possess of the way etymology was practiced from the 5th century on is justified in that, by modern standards of etymological critical rigor, it seems totally implausible. This however would 
we can be certain that no one ever divined the true etymon of the words in verse for as much as their etymologizing never left the space of a "logocentric" organization of meaning which, qua "logocentric", was by definition incapable of encoding what then counted as the truth [4].

Still, this does not change three key facts: (1) the assumption by everyone that the ordinary meanings of words contained an etymonic "true meaning" somewhere in its phonetic depths; (2) that this "true meaning" was the one placed there by a Seer-Poet by virtue of the way he cunningly combined melody and rhythm with prosaic words and language to make the former an alethophoric

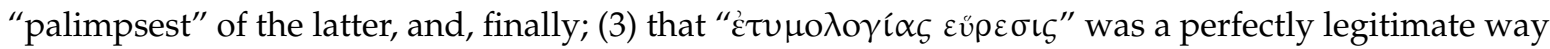
of unearthing and enfleshing this hidden "true meaning" of ordinary words ([53], p. 136). All that was required was to (i) listen to the melody and rhythm accompanying the words used in the poet's composition; (ii) correctly identify what these musical arrangements of sound meant; and (iii) justify assuming that the conjectured meaning was the etymon of the prosaic words used in verse by reference to the phonetics that was common both to those words and to the accompanying melody and rhythm ${ }^{25}$.

This is significant for us because it was the belief that it was possible, albeit only in part, to access and exhume the hidden, musically-encoded etymon of words which resulted in a certain deterritorialization of the ordinary meaning of ordinary words. For, again, it is impossible to speculate about the poetico-musical meaning of ordinary words and language without ipso facto "deporting" them from their ordinary meanings. And it is all the more impossible if the point of engaging in this speculation was to confer "true" rather than merely "doxastic" meaning on them ${ }^{26}$. However, it is unlikely that the "deterritorialization" of the ordinary meanings of words ever resulted in a full "reterritorialization" on the terrain of poetic truth. In any case, it is doubtful that this deterritiorialization-reterritorialization was feasible unless it was conducted by an experienced poet-and for "professional reasons" they were not keen on doing this in public. But even if for this reason a full reterritorialization could never succeed entirely, nor could it entirely fail either. For, as we suggested above, the poet's audience was always sufficiently knowledgeable of the semiotic subtleties of versecraft that at least the essentials of the Rhapsodes' message were legible to them. Which is important to stress here because it was the cumulative effect of this "failure to fail entirely" in converting poetic truth into the etymonic signifié of ordinary language which resulted—in some measure-in making "musical" meaning the etymonic truth of words. That is why the title of this paper speaks of an "antagonistic concord" linking and not linking musical semiosis and lexical semiosis. For between the twain there was an aspirational semiotic concordance, but of certainty that any hermeneute ever succeeded in consummating that aspiration, there was none. That, however, never discouraged those who wanted to attain this

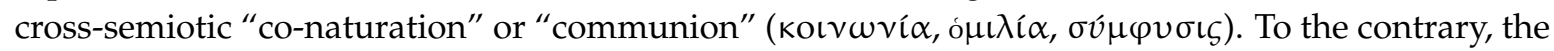
difficulty of apprehending the tidings Muses, Sirens, Silenes, and Pans transmitted through and as

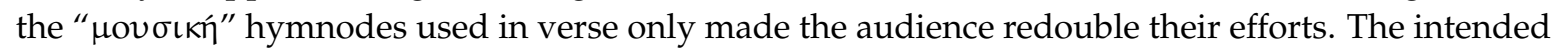
reterritorialisation therefore progressed-by virtue of the impossibility of ever reaching the goal it was the whole point of progressing to attain. That is to say, the enchanting hierophonia one sought and was promised by listening to verse never quite came within the reach of the words one used to "comprehend" or "grasp" the promised enchantment. But it was always ever so tantalizingly close. Quite literally just

amount to overlooking the distinction Timothy Baxter makes between "semantic" and "mimetic" etymologizing ([56], pp. 5-6) and the likelihood that the former, dominant from the 5th century on, was conducted without a knowledge of "poetic" lore about the origins and nature of words and language and the way the latter are supposed to be "mimetically" linked to the truth about what their referents stand for.

25 In modern times, those who have come closest to discerning how this etymology worked in practice are those who have adapted Saussure's theory of "anagrammes" to the investigation of what is referred to as 'the Language of the Gods' (e.g., [26,28,57]). However-and unfortunately-all who do so pass over in silence the connection between musical meaning and linguistic meaning and the dependence of the latter upon the former.

26 Even though he was unconcerned with making musically encoded meaning the etymon of words, M.L. West's remarks in ([11], pp. 78-79) on "lexical renewal" can nonetheless be consulted to see how this process most probably worked. However, an even better description of the deterritorialization we are thinking of here is Bakhtin's account in [16] of the way "primary speech genres" are altered and restructured by the "secondary speech genres" that absorb them. 
under the surface of the words used to seize it, resonating audibly in their very phonetic condition of possibility. Fair game, therefore, for the etymological Don Quixotes who never tired of trying to pin down its beguiling hyponoia perpetually that one hermeneutical remove out of reach. This intersemiotic enterprise was therefore open-ended, on-going, unending. That is to say endlessly fruitful in its fruitlessness-and for that very reason endlessly enchanting.

\section{Recapitulation and Concluding Remarks}

The foregoing looked at one of the ways in which the relationship between "music", "poetry", and "language" differed from the way they relate to each other today. For while each remained a distinct, independent "semiosphere" expressing a semiosis all its own, these separated meanings nonetheless never ceased growing into and out of each other. This is so because music and poetry were accepted as having the capacity to denote something ordinary language could not denote but could not do without, namely "etymonic truth". As a result, the users of ordinary language were obsessed with divining the "hyponoia" poets and rhapsodes encoded in music and chant. Above all, they wanted this hyponoia to constitute the signifié of their language. What we discovered is that, for this reason, the meaning expressed in language was subject to a process in which it was constantly being "deported" from its ordinary semantic acceptations and applications and "transported" towards meanings encoded in music. But this "deterritorialization" of ordinary meaning never resulted in a full "reterritorialization" upon the terrain of the truth encoded in music. Musicians and poets would not tolerate it. As far as they were concerned, music and poetry would cease being truthful if the semiosis they conveyed and the semiosis conveyed by language were interchangeable. Again, as a code, prosaic language was sui generis incapable of representing the truth. Hence, the relationship between the three codes or media consisted of a sort of "intersemiotic dynamic equilibrium" in which, thanks to the hermeneutical role of the poet, language was continuously evolving towards a non-linguistic expression of meaning which conferred truth upon it and what it means. Yet the music and poetry which were the source of that truth, deliberately kept language from consummating the aspiration of accosting and appropriating the truth they encoded. This left those who were addicted to divining the meaning of the music accompanying verse no choice but to redouble their efforts to realize a quest no degree of effort could ever succeed in consummating.

Conflicts of Interest: The author declares no conflict of interest.

\section{References}

1. John Herington. Poetry into Drama: Early Tragedy and the Greek Poetic Tradition. Berkeley: University of California Press, 1985.

2. William D. Furley, and Jan Maarten Bremer. Greek Hymns: Selected Cult Songs from the Archaic to the Hellenistic Period. Tübingen: Mohr Siebeck, 2001.

3. Gregory Nagy. Pindar's Homer. Baltimore: John Hopkins University Press, 1990.

4. Jenny Strauss Clay. "The Homeric Hymns." In A New Companion to Homer. Edited by Ian Morris and Barry B. Powell. Leiden: Brill, 1997, pp. 489-507.

5. Barbara Kowalzig. Singing for the Gods: Performances of Myth and Ritual in Archaic and Classical Greece. Oxford: Oxford University Press, 2007.

6. Andrew Faulkner, and Owen Hodkinson. Hymnic Narrative and the Narratology of Greek Hymns. Leiden: Brill, 2015.

7. Lutz Käppel. Paian: Studien zur Geschichte einer Gattung. Berlin: W. de Gruyter, 1992.

8. James Bradley Wells. "Lyric and Lyrics: Perspectives, Ancient and Modern." In The Cambridge Companion to Greek Lyric. Edited by F. Budelmann. Cambridge: Cambridge University Press, 2015, pp. 155-74.

9. Claude Calame. "La poésie lyrique grecque, un genre inexistant? " Littérature 111 (1998): 87-110. [CrossRef]

10. Pierre Boyancé. Le Culte des Muses Chez les Philosophes grecs: Etudes D'histoire et de Psychologie Religieuses. Paris: Ed. de Broccard, 1936.

11. Martin L. West. Indo-European Poetry and Myth. Oxford: Oxford University Press, 2007. 
12. Boris Maslov. "The Real Life of the Genre of Prooimion." Classical Philology 107 (2012): 191-205. [CrossRef]

13. George Walsh. The Varieties of Enchantment: Early Greek Views of the Nature and Function of Poetry. Chapell Hill: University of North Carolina Press, 1984.

14. Martin Heidegger. Der Satz vom Grund. Pfullingen: Verlag Gunther Neske, 1957.

15. Jacques Derrida. Marges de la philosophie. Paris: Minuit, 1972.

16. Mikhail Bakhtin. Speech Genres and Other Late Essays. Austin: University of Texas Press, 1986.

17. Jean Molino. Le Singe Musicien, Sémiologie et Anthropologie de la Musique. Arles: Actes Sud, 2009.

18. Gérard Genette. Mimologiques, Voyage en Cratylie. Paris: Seuil, 1976.

19. Jean Starobinski. Les Mots Sous les Mots. Paris: Gallimard, 1971.

20. Milman Parry. Les Formules et la Métrique d'Homère. Paris: Les Belles Lettres, 1928.

21. Jean-Pierre Vernant. Mythe et Pensée Chez les Grecs. Paris: La Découvert, 1996.

22. Moses I. Finley. The World of Odysseus. London: Chatto \& Windus, 1954.

23. Marcel Detienne. Les Maîtres de la Vérité Dans la Grece Archaïque. Paris: L'Ouverture, 1994.

24. Matthew Clark. "Formulas, metre and type scenes." In The Cambridge Companion to Homer. Edited by Robert L. Fowler. Cambridge: Cambridge University Press, 2004, pp. 117-38.

25. Christos Tsagalis. The Oral Palimpsest, Exploring Intertextuality in the Homeric Epics. Cambridge: Harvard University Press, 2008.

26. Calvert Watkins. How to Kill a Dragon. Oxford: Oxford University Press, 1995.

27. Elroy T. Bundy. Studia Pindarica. Berkeley: University of California Press, 1962.

28. Françoise Bader. La Langue des Dieux ou L'hermétisme des Poètes Indo-Européens. Pisa: Giardini, 1989.

29. John Hamilton. Soliciting Darkness: Pindar, Obscurity, and the Classical Tradition. Cambridge: Harvard University Department of Comparative Literature, 2003.

30. Thrasybulos Georgiades. Musik und Rhythmus bei den Griechen. Hamburg: Rowohlt, 1958.

31. Walter F. Otto. Essais sur le Mythe. Translated by Pascal David. Mauvezin: Trans-Europ-Repress, 1987.

32. Hermann Koller. "Stoicheion." Glotta 34 (1955): 161-74.

33. Marius Schneider. "Die Natur des Lobgesangs." In Basilienses de Musica Orations 2. Basel: Bärenreiter, 1964, pp. 5-19.

34. Andrew Ford. Homer: The Poetry of the Past. London: Cornell University Press, 1992.

35. Maurus Hirschle. Sprachphilosophie und Namenmagie im Neuplatonismus. Meisenheim am Glan: A. Hain, 1979.

36. Félix Buffière. Les Mythes d'Homère et la Pensée Grecque. Paris: Les Belles Lettres, 1973.

37. Peter Struck. Birth of the Symbol: Ancient Readers at the Limits of their Texts. Princeton: Princeton University Press, 2004.

38. Eric Csapo. "Star Choruses: Eleusis, Orphism, and New Musical Imagery and Dance." In Performance, Iconography, Reception: Studies in Honour of Oliver Taplin. Edited by Martin Revermann and Peter Wilson. Oxford: Oxford University Press, 2008, pp. 264-67.

39. Timothy Power. The Culture of Kitharôidia. Washington and Cambridge: Harvard University Press, 2010.

40. Martin L. West. “Alcman and Pythagoras.” Classical Quarterly 17 (1967): 1-15. [CrossRef]

41. Eric Havelock. Preface to Plato. Cambridge: The Belknap Press, 1963.

42. Frits Staal. The Fidelity of Oral Tradition and the Origins of Science. Amsterdam: North-Holland Publishing Company, 1986.

43. André Padoux. L'énergie de la Parole: Cosmogonies de la Parole Tantrique. Paris: Fata Morgana, 1994.

44. Robert A. Yelle. Explaining Mantras: Ritual, Rhetoric and the Dream of a Natural Language in Hindu Tantra. New York: Routledge, 2003.

45. Armand Delatte. Etudes sur la Littérature Pythagoricienne. Paris: E. Champion, 1915.

46. Pierre Boyancé. "Note sur la Tétractys." L'Antiquité Classique XX (1951): 421-25.

47. Fionn Bennett. "Translating the Facts of Landscape into the Facts of Language: Ethnoecological Ruminations on Glossopoiesis in Early Ireland." In Irish Contemporary Landscapes in Literature and the Arts. Edited by Marie Mianowski. London: Palgrave Macmillan, 2012, pp. 39-50.

48. Richard Martin. “Telemachus and the Last Hero Song." Colby Quarterly 29 (1993): 222-40.

49. Egbert. J. Bakker. Poetry and Speech: Orality and Homeric Discourse. Ithaca: Cornell University Press, 1997.

50. John F. Garcia. "Ritual Speech in Early Greek Song." In Epea \& Grammata: Oral E Written Communication in Ancient Greece. Edited by Ian Worthington and John Miles Foley. Brill: Leiden, 2002, pp. 29-53. 
51. Henri-Irénée Marrou. Historie de l'éducation dans l'Antiquité, Le Monde Grec. Paris: Editions du Seuil, 1948, vol. 1.

52. Penelope Murray, and Peter Wilson. Music and the Muses: The Culture of "Mousike" in the Classical Athenian City. Oxford: Oxford University Press, 2004.

53. Jean Lallot. “L'étymologie chez les grammairiens grecs: Principes et pratique." Revue de Philologie, de littérature et D'histoire Anciennes 65 (1991): 135-48.

54. Jean Pepin. Myth et Allégorie: Les Origines Grecques et les Contestations Judéo-Chrétiennes. Paris: Etudes Augustiniennes, 1976.

55. James J. O'Hara. True Names: Virgil and the Alexandrian Tradition of Word Play. Ann Arbor: University of Michigan Press, 1996.

56. Timothy Baxter. The "Cratylus": Plato's Critique of Naming. Leiden: E.J. Brill, 1992.

57. Vladimir N. Toporov. “Die Ursprünge der indogermanische Poetik." Poetica 13 (1981): 189-251.

(C) 2016 by the author; licensee MDPI, Basel, Switzerland. This article is an open access article distributed under the terms and conditions of the Creative Commons by Attribution (CC-BY) license (http://creativecommons.org/licenses/by/4.0/). 